Journal of Social Sciences 6 (4): 523-528, 2010

ISSN 1549-3652

(C) 2010 Science Publications

\title{
Sexting, Texting, Cyberbullying and Keeping Youth Safe Online
}

\author{
Robin D'Antona, Meline Kevorkian and Ashley Russom \\ Nova Southeastern University, Ft. Lauderdale, FL., USA
}

\begin{abstract}
Problem statement: The issue of cyberbullying is one that has raised the concerns of parents, educators and law enforcement. Today children have cell phones with internet access as young as age eleven and some have cell phones as young as age eight making them all vulnerable to cyberbullying. Approach: The aim of this study was to explore differences between third, fourth and fifth graders perceptions of cyberbullying as a function of having a cell phone, by gender and grade. Data was collected from 835 third, fourth and fifth graders in Massachusetts. Results: An analysis of the data revealed that $35 \%$ of third, fourth and fifth graders had their own cell phone, $11.4 \%$ responded that they had received mean or hurtful email or text messages about them and $45.6 \%$ of the students responded that they had been bullied in school. Differences by grade and gender were examined. Results indicate that although $27 \%$ of respondents worry about being bullied online, only $12 \%$ had someone talk to them about bullying online. Students in third grade were more in agreement that they worry about being bullied online and more strongly reported being afraid of being bullied by other students at school. Female respondents were more in agreement with the prevalence of cyberbullying or receiving hurtful emails and text messages about them and others. Conclusion: The findings suggest that students are provided with technology at young ages and receive very little guidance to protect them from cyberbullying.
\end{abstract}

Key words: Bullying, cyberbullying, online safety, school bullying, school safety, sexting, texting

\section{INTRODUCTION}

The virtual world poses both opportunities and risks for generation net. A number of factors influence those risks and opportunities. Educators and parents must be cognizant of the preference for technology over face to face interaction and must help guide children with safe online practices. Increased media attention to cyberbullying and online behavior emphasizes that many young people are concerned about both the real and virtual world. Given guidelines and provided with training on the risks with technology and online activity, our children can prevent cyberbullying and protect their online reputation.

For most children, sexting and texting are part of the online behaviors on which children are spending more and more of their time. Cyberbullying threatens the overall well being of our children and teenagers and there is little research that studies online behaviors of elementary age children that offers insight to their perceptions of the virtual world. Adults must understand the following five key areas that help keep the cyber interactions of children safe and healthy: technology use in children and youth; prevalence and impact of cyberbullying; sexting; texting and online reputation; the social and emotional side of bullying and preventing cyberbullying.

Technology use in children and youth: Mishna et al. (2009) found that children are using technology at younger ages and that by underestimating their usage we may be failing to protect children from the dangers. As a parallel to Mishna et al. (2009), this study collected data, from 835 third, fourth and fifth graders in Massachusetts, approximately $23 \%$ of third and fourth graders have their own cell phone and in fifth grade that number doubles to approximately 55\%. Mishna et al. (2009) findings support that cyberbullying occurs in front of peers and there are usually bystanders as in traditional bullying. Mishna et al. (2009) also reported that almost all children stated they would not share with their parents that they have experienced or witnessed cyberbullying. This supports the notion that adults must be aware and trained on how to guide children through cyber interactions to prevent cyberbullying.

Prevalence and impact of cyberbullying: Li (2006) and Luan et al. (2008) found that cyberbullying is prevalent in our schools, that over a third of the cyber 
victims had been harassed multiple times and that lose to half of the cyber bullies had bullied others more than three times using electronic means. Ybarra et al. (2006) support findings with their own findings that with traditional bullying, boys are more likely to bully than girls, however with online bullying, the incidents are equal. Boys are as likely as girls to bully others online. Data from the Second Youth Internet Safety Study (YISS-2, a national survey of 1,500 households of youth between the ages to 10-17) by Ybarra et al. (2006) showed that 1 in 3 youth reported that they had harassed someone online at last once in the previous year. Of the youth who said they harassed someone online, $82 \%$ said that someone else had said mean or hurtful things about them online. Cassidy et al. (2009) determined that young people want to dialogue about cyberbullying and suggest that schools need to provide opportunity for students to discuss cyberbullying, its impact and ways to prevent this behavior.

Over the last decade, research shows that cyberbullying has expanded and has become recognized as a serious issue among our youth (Ybarra and Mitchell, 2004). Cell phones and internet communication do not allow the opportunity for the parties to read visual clues. It is difficult if not impossible for children to know the impact of their communication. This anonymity can lead to serious aggression. Internet harassment is a health issue for both the harasser and the victim. They are subject to the same psychological stressors as other forms of bullying.

Educators, parents and law enforcement officials deal with the issues of cyberbullying with victims, perpetrators and bystanders. Before we can tackle this problem we must understand the online behavior of our children and understand their perceptions regarding cyberbullying and online activity overall. Students who are cyberbullied experience depression, anxiety, difficulty concentrating and often want to miss school. Ybarra and Mitchell (2007) support that students who perpetrate cyberbullying are more likely to engage in risky behavior. Students who receive these texts and view cyberbullying online also feel nervous and anxious over the exposure. Wang et al. (2009) discussed that positive parental behaviors protected adolescents from both bullying and being bullied, including cyberbullying.

Sexting, texting and online reputation: In a study by PEW Internet and American Life Project, Lenhart and Madden (2007) reported that more than half of adolescents ages 12-18 had cell phones. Texting is regularly used among young people and more than $73 \%$ of teens to communicate. Additionally, over $55 \%$ teens age 12-17 use social networks with a posted profile and picture. Kowalski et al. (2007) define sexting as sending a text containing a nude or sexually explicit photo. It is essential to make students aware that these texts could be sent to thousands with a few clicks. Once disseminated, these photos and texts can harm their reputation and even constitute criminal activity. Research supports that sexting may have long term consequences that impact the future such as higher education choices and employment opportunities (Kowalski et al. 2007).

Kowalski et al. (2007) note that teens do not connect the risky sexting behavior with the possibility of any negative outcomes, because their brains are not fully developed; particularly the pre-fontal cortex that assesses risks and considers consequences. Additionally, they reinforce that parents need to talk to their children about the possible risks and dangers to themselves and others. Diliberto and Mattey (2009) discusses the role school nurses could play in schools to educate students and parents to both prevent legal action that may result from sexting and cyberbullying and to alert students and parents to the emotional stress that often accompany these behaviors. Cassidy et al. (2009) reported that students want to talk about cyberbullying and be involved as part of the solution. They also found that students were more likely to report cyberbullying about another student than they were to report it when it happened to them.

Cassidy et al. (2009) supports that cyberbullying takes place among groups of friends. Ybarra and Mitchell (2004) discuss how when there is poor caregiver monitoring of online behavior the children are twice as likely to harass others online. Also, youth who report not having a close relationship with their care givers are 3 times more likely to harass others online. This supports the need for adults to monitor carefully what their children are doing in cyberspace. Cassidy et al. (2009) noted that given a choice of solutions for cyberbullying, the top four were "setting up anonymous phone lines where students can report cyber-bullying;... developing programs to teach students about cyber-bullying and its effects;...punishing students who participate in cyberbullying;...[and] working on creating positive selfesteem in students."

One in five teens participates in "sexting", according to a nationwide survey by the National Campaign to Prevent Teen and Unplanned Pregnancy. The American Academy of Pediatrics (AAP) recommends that parents should talk with children about sexting as soon as a child is old enough to have a cell phone. AAP suggests asking kids about the issue, even if they have not been impacted directly, with an 
age-appropriate explanation. For very young children, this could be explaining that text messages should never contain pictures of kids or adults without their clothes on, kissing, or touching each other. For older children and teens, explain that "sexting" often involves pictures of a sexual nature and is considered pornography. Parents, schools and all those who care for children and teens need to understand how to prevent misuse and abuse of cell phone and other media applications. This includes promoting positive online behavior in the cyber world.

Ybarra and Mitchell (2007) define interpersonal Internet victimization as the report of unwanted sexual solicitation or harassment over the Internet. Requests to engage in sexual activities, sexual talk or an invitation to reveal personal sexual information are all elements of the category of unwanted sexual solicitation or harassment. The possession and production of child pornography is against the law. Youth need to know that if they participate in texting it is not only immoral, it can be illegal.

The social and emotional side of bullying: Aggression and victimization in child and adolescent peer groups compromises children's safety and development (Snyder et al., 2003). In both the aggressor and victim, bullying is sign of potential psychiatric disorders (Turkel, 2007). Social-cognitive approaches may be useful in preventing relational aggression. Culotta and Goldstein (2008) found a significantly high correlation of relational aggression with jealousy; adolescents who reported being more jealous than peers engaged in more relation aggression. These jealous adolescents may motivate bullying behaviors. Girls' reported higher levels of jealousy. These findings suggest that gender be considered when in intervention and prevention efforts.

The ability to develop and maintain healthy relationships are important skills for children to learn. As a child grows into adolescence, peer relationships are of increasing importance and positive peer interaction during adolescence is an indicator of the ability to maintain successful relationships in adulthood (McElhaney et al., 2008). As they grow, they are confronted with peer pressure and interpersonal conflicts. Bullying negatively impacts children and adolescents' abilities to create peer relationships and maintain a healthy lifestyle (Dake et al., 2003; McElhaney et al., 2008; Sumalatha and Ramakrishnaiah, 2004). When children know how to choose and maintain good friends, they feel confident and safe. Responsible decision making is about putting the social and ethical skills to action. Children need to be guided to make responsible decisions based on respect, personal safety and empathy for others and a clear understanding of the consequences.

Preventing cyberbullying: With the introduction of electronic communication, kids have been able to expand the ways they can hurt one another. This can be done by sending cruel or threatening emails and text messages. Students can spread rumors online and set up websites that poke fun at someone. There are chat rooms, blogs and social networking websites that are available to all who wish to participate. These can be filled with nontruths, damaging lies, personal information and embarrassing secrets about a student. This information can be transmitted to an entire student body and beyond with a simple click of a button. Once the information is out there, whether it is true or not does not matter. Others can simply pick up on it and expand on it to even greater levels of cruelty. When the victim is not in front of them, kids seem to become much braver and are willing to send or forward mean messages. Parents should be familiar with whom their children are communicating and know their online and cellular friends just as we know the friends in their class, school, or in the neighborhood.

The use of text messaging and other global communication media has made exposure to cyberbullying more commonplace and children are no longer safe when in the proximity of adults. Many children think that text messages disappear and are only between the sender and the recipient or recipients. Let them know that they become part of the virtual world and can be retrieved if necessary. Additionally, messages may be forwarded and shared with others for whom they were not intended.

We would not allow children to enter places that exposed them to alcohol, drugs, guns and other risks and dangers. Likewise, we should be discriminating about the virtual places children and teens visit. Parents need to protect their children as well as take responsibility for their use of technology. Some cell phones allow children to take pictures, type text messages and access the Internet, anywhere and anytime, which can allow them to bully other kids $24 \mathrm{~h}$ a day and seven days a week.

There are bystanders in the virtual world and they need adult intervention as well as those who are the perpetrators and victims of cyberbullying. Kids need to understand that by reading the cyberbullying material they are participants and equally responsible for the hurt. Correspondence over the Internet via e-mail, text messages, postings and instant messaging has an informality that allows for any font and an acceptance of ignoring basic grammar and spelling. There is a lingo 
with shortcuts to send messages in few words and letters. This quick approach to virtual communication often leads to quick responses with little thought to how a message may be interpreted or utilized.

Online harassment and bullying may impact a child's ability to concentrate in school, their involvement in extracurricular activities, their selfesteem and even their desire to stay in school. Schools must educate students and parents about cyberbullying to protect the learning environment. This means helping everyone to understand the nature of cyberbullying and how the access is infinite.

\section{MATERIALS AND METHODS}

The purpose of this study was to explore the differences in perceptions of third to fifth grade students regarding bullying and cyberbullying. Differences in gender and grade were also explored.

\section{Research questions:}

- Does the perception of the prevalence of cyberbullying differ with respect to having a grade and gender?

- Does the perception of worrying about being bullied online for third to fifth grade students differ with respect to having a cell phone, grade and gender?

- Does the prevalence of having someone talk to them about bullying online for third to fifth grade students differ with respect to grade and gender?

Participants: Eight hundred thirty-five third to fifth grade students completed the survey. The general sample included 423 boys and 412 girl participants. Approximately $0.03 \%$ of the participants were AfricanAmerican, 97.7\% were White, non-Hispanic, $0.08 \%$ was White, Hispanic and $2.19 \%$ were of other ethnic origin.

Instrument: The survey gathered perceptions towards bullying and cyber-bullying among third through fifth grade students in a school district in Massachusetts.

This 47 item survey was a self-administered, questionnaire that participants were able to complete independently. The survey contained questions to obtain student's perceptions of cyberbullying. The survey consisted of three factors: (a) prevalence of cyberbullying, (b) comfort level of dealing with cyberbullying and (c) adult intervention in cyberbullying. The survey included both ordinal and nominal response choices. The survey included 4 demographic questions regarding gender, grade and having a cell phone. Responses to the questions were either coded as (a) a Likert scale from 1 (strongly agree) to 5 (strongly disagree); (b) yes, no; Or (c) a numerical choice.

Procedures: The data was collected by the school district as part of their bullying prevention initiative. This archival data was utilized to explore perceptions of third through fifth grade students regarding cyberbullying. The mean of the participants' response to various questions were examined by gender and grade.

\section{RESULTS}

Sexting, texting, cyberbullying and online reputation must be addressed with young people to help keep them safe and protect their future. The perceptions regarding cyberbullying were analyzed from an archival survey of bullying and cyberbullying of third through fifth grade students. Differences in perceptions of cyberbullying in regards to gender and grade were examined.

Research question 1: Does the perception of the prevalence of cyberbullying differ with respect to having a grade and gender? Differences by gender were found on the prevalence of cyberbullying. The participants were asked to rate if they felt they have received mean or hurtful text messages about them by responding yes or no. Overall, $6.3 \%$ of respondents said they have received mean or hurtful text messages about them and $10 \%$ have received these same kinds of messages about others. Approximately $67 \%$ of the responses that indicated they have received mean or hurtful text messages about them and the $57 \%$ who had received mean or hurtful text messages about others were female. No differences were reported by grade level.

Research question 2: Does the prevalence of worrying about being bullied online for third to fifth grade students differ with respect to grade and gender? Differences by grade level and gender were found on the prevalence of worrying about being bullied online for third to fifth grade students. Overall, $27 \%$ of respondents reported being worried about bullying online. Worrying about being bullied online decreased as children advanced in grade. For third graders, $36.3 \%$ reported worrying about being bullied online, for fourth graders, $27.7 \%$ reported worrying about being bullied online and for fifth graders, $18 \%$ reported worrying about being bullied online. In regards to gender, $31.3 \%$ of females responded being worried about being bullied online and $22.8 \%$ of males responded being worried about being bullied online. 
Research question 3: Does the prevalence of having someone talk to them about bullying online for third to fifth grade students differ with respect to grade and gender? Differences by grade level and gender were found on the prevalence of having someone talk to them about bullying online for third to fifth grade students. Overall, $11.9 \%$ of respondents reported being worried about bullying online. Having someone talk to them about bullying online increased slightly as students entered fifth grade. For third graders, 10.9\% reported having someone talk to them about bullying online, for fourth graders, $10 \%$ reported having someone talk to them about bullying online and for fifth graders, $14.4 \%$ reported having someone talk to them about bullying online. In regards to gender, $14.5 \%$ of females responded having someone talks to them about bullying online and $9.4 \%$ of males responded having someone talk to them about bullying online.

\section{DISCUSSION}

The findings from this study indicate that elementary age children are concerned about cyberbullying and may benefit from discussions that foster online and media safety and bullying prevention. Analysis of data found that $27 \%$ of third through fifth graders worry about being bullied online and only $11.9 \%$ report having had someone talk to them about bullying online. These findings support the need to equip our children, as young as possible, about the technology they are growing up with. A little over a $33 \%$ of third graders report worrying about being bullied online. Educators and parents should incorporate the knowledge to prevent cyberbullying and keep our kids safe in the virtual world. These findings support the notion that that it is never too early to address online behavior to prevent sexting, texting, cyberbullying and online reputation.

To assist with preventing cyberbullying and keeping youth safe online, parents should:

- Demonstrate caring and concern for others in your virtual interactions and discuss responsible decision-making

- Include regular communication about online friends and virtual communication as a part of maintaining a healthy parent child relationship and regular and open family communication and discussion

- Know the technology and virtual locations regularly accessed by children and teens and their respective parental controls and safety features

- Stay vigilant as technology is constantly changing
- Provide opportunities for your child to practice your morals and values virtually as you do in other areas within your community

- Monitor and supervise all virtual communication and reinforce the consequences of inappropriate communication including legal ramifications of certain online behaviors

- Remind children not to write or do anything that they would not want to be seen publicly as the internet is an unregulated public forum and nothing is private

To assist with preventing cyberbullying and keeping youth safe online, educators and educational leaders should:

- Include virtual interactions in developing and modeling empathy and compassion in the virtual world

- Provide training and professional development on appropriate and acceptable virtual interactions for students, parents, educators

- Include virtual scenarios and issues in regular and ongoing bullying prevention efforts for all stakeholders

- Provide opportunities for parents to receive training on the technology their children are regularly accessing to keep them safe and healthy

- Gather perspectives of online behaviors from students and put in place effective measures to monitor and supervise virtual interactions

- Incorporate online safety principles in their policies, procedures and curriculum

- Collaborate with the media center and local libraries in providing resources to promote information literacy to help students to navigate the internet and locate valid online content and resources

\section{CONCLUSION}

Clearly the research indicates that unmonitored access to the Internet can place students in danger and cyberbullying has increased at alarming rates (Beale and Hall, 2007). Unlimited access provided by most cell phones can allow for text messaging and other tools to exclude or hurt others (Kowalski and Limber, 2007). Cell phones with texting and Internet access are an integral part of the virtual landscape of the youth today. Although the availability of technology for children is ever increasing, students are telling us that they are given these tools with little or no instruction about how to protect themselves from the dangers of cyberbullying. 
To prevent cyberbullying and keep youth safe online we need to do a better job discussing and educating our children, embedding this education in the primary grades. In addition, schools should gather information from students to find out in they worry about being bullied online and if adults are communicating with them about online activities and behaviors. Educators and school leaders need training specific to cyberbullying so they in turn can talk to students about the dangers of cyberbullying and help parents reinforce a message of safety and respect. Cyberbullying and online interactions impact their school and learning experience and must be an integral part of providing and safe and bully free learning environment.

\section{REFERENCES}

Beale, A.W. and K.R. Hall, 2007. Cyberbullying: What school administrators (and parents) can do? Clear. House, 81: 8-12. DOI: 10.3200/TCHS.81.1.8-12

Cassidy, W., M. Jackson and K.N. Brown, 2009. Sticks and stones can break my bones, but how can pixels hurt me? School Psychol. Int., 30: 383-402. DOI: 10.1177/0143034309106948

Culotta, C.M. and S.E. Goldstein, 2008. Adolescents' aggressive and prosocial behavior: Associations with jealousy and social anxiety. J. Gene. Psychol., 169: 21-33. DOI: 10.3200/GNTP.169.1.21-33

Dake, J.A., J.H. Price and S.K. Telljohann, 2003. The nature and extent of bullying at school. J. School Health, 73: 173-201. DOI: 10.1111/j.17461561.2003.tb03599.x

Diliberto, G.M. and E. Mattey, 2009. Sexting: Just how much of a danger is it and what can school nurses do about it? School Nurse, 24: 262-267. DOI: 10.1177/1942602X09348652

Kowalski, R.M., S.P. Limber and P.W. Agatston, 2007. Cyberbullying: Bullying in the Digital Age. 1st Edn., Wiley-Blackwell, USA., ISBN: 10: 1405159928, pp: 224.

Kowalski, R.M. and S.P. Limber, 2007. Electronic bullying among middle school students. J. Adolesc. Health, 41: S22-S30. DOI: 10.1016/j.jadohealth.2007.08.017

Lenhart, A., and M. Madden, 2007. Teens, privacy and online social networks. Pew Internet and American Life Project.

http://www.pewinternet.org/ /media//Files/Reports /2007/PIP_Teens_Privacy_SNS_Report_Final.pdf. pdf

Li, Q., 2006. Cyberbullying in schools a research of gender differences. School Psychol. Int., 27: 157-170. DOI: $10.1177 / 0143034306064547$
Luan, W.S., N. Siew F. and H. Atan, 2008. Gender differences in the usage and attitudes toward the internet among student teachers in a public Malaysian University. Am. J. Applied Sci., 5: 689-697. DOI: $10.3844 / .2008 .689 .697$

McElhaney, K.B., J. Antonishak and J.P. Allen, 2008. "They like me, they like me not": Popularity and adolescents' perceptions of acceptance predicting social functioning over time. Child Dev., 79: 720-731. DOI: 10.1111/j.1467-8624.2008.01153.x

Mishna, F., M. Saini and S. Solomon, 2009. Ongoing and online: Children and youth's perceptions of cyber bullying. Child. Youth Serv. Rev., 31: 1222-1228. DOI: 10.1016/j.childyouth.2009.05.004

Snyder, J., M. Brooker, M.R. Patrick, A. Snyder and L. Schrepferman et al., 2003. Observed peer victimization during early elementary school: Continuity, growth and relation to risk for child antisocial and depressive behavior. Child Dev., 74: $\quad 1881-1898 . \quad$ DOI: $\quad 10.1046 / j .1467-$ 8624.2003.00644.x

Sumalatha, K. and D. Ramakrishnaiah, 2004. Sex bias in secondary school social studies textbooks: A case study in India. Am. J. Applied Sci., 1: 62-63. DOI: $10.3844 / .2004 .62 .63$

Turkel, A., 2007. Sugar and spice and puppy dogs' tails: The psychodynamics of bullying. J. Am. Acad. Psychoanal. Dyn. Psychiatry, 35: 243-258. DOI: 10.1521/jaap.2007.35.2.243

Ybarra, M.L. and K.J. Mitchell, 2004. Youth engaging in online harassment: Associations with caregiverchild relationships, internet use and personal characteristics. J. Adolesc., 27: 319-336. DOI: 10.1016/j.adolescence.2004.03.007

Ybarra, M.L. and K.J. Mitchell, 2007. Prevalence and frequency of internet harassment instigation: Implications for adolescent health. J. Adolesc. Health, 41: 189-195. DOI: 10.1016/j.jadohealth.2007.03.005

Ybarra, M.L., K.J. Mitchell, J. Wolak and D. Finkelhor, 2006. Examining characteristics and associated distress related to internet harassment: Findings from the second youth internet safety survey. Pediatrics, 118: e1169-e1178. DOI: 10.1542/peds.2006-0815

Wang, J., R.J. Iannotti and T.R Nansel, 2009. School bullying among adolescents in the United States: Physical, verbal, relational and cyber. J. Adolesc. Health, 45: 368-375. DOI: 10.1016/j.jadohealth.2009.03.021 